\title{
Transformasi Pembelajaran Sekolah Minggu yang Memerdekakan di Gereja pada Masa Kenormalan Baru
}

\author{
Sjeny Liza Souisa \\ Institut Agama Kristen Negeri Ambon \\ souisa.sjeny@gmail.com
}

\begin{abstract}
The Covid-19 pandemic has had an impact on various sectors of life, including religious activities. Worship and ecclesiastical ministry at a certain time must be transferred to the virtual world, including Sunday School services. After going through such a long time, finally, everyone is ready to enter the new normal. This paper aims to show a transformation of Sunday School learning in the new romantic era. Sunday School in a new era of romance. Learning in the new normal era promotes learning that is fun, effective, recreational, democratic, empathic, creative, and active, or abbreviated as so-called "MERDEKA".
\end{abstract}

Keywords: Covid-19 pandemic; new normal; Sunday school

\begin{abstract}
Abstrak: Pandemi Covid-19 telah menghasilkan dampak di berbagai sektor kehidupan, termasuk kegiatan keagamaan. Ibadah dan pelayanan gerejawi dalam waktu tertentu harus dialihkan ke dunia virtual, termasuk pelyanan Sekolah Minggu. Setelah melewati waktu yang begitu panjang, akhirnya semua bersiap untuk masuk pada kenormalan baru (new normal). Paper ini bertujuan untuk menunjukkan sebuah transformasi pembelajaran Sekolah Minggu di era kenromalan baru. Pembelajaran di era kenormalan baru mengusung permbelajaran yang menyenangkan, efektif, rekreatif, demokratis, empatik, kreatif, dan aktif, atau disingkat "MERDEKA".
\end{abstract}

Kata kunci: kenormalan baru; pandemi Covid-19; sekolah minggu

\section{Pendahuluan}

Kehadiran virus Covid-19 juga mengakibatkan terjadinya pergeseran dari proses pembelajaran tatap muka secara langsung antara pendidik dengan peserta didik menjadi pembelajaran online atau pembelajaran jarak jauh. Pembelajaran online atau pembelajaran jarak jauh telah lama menjadi perbincangan hangat dalam dunia pendidikan, baik di Negaranegara maju atau negara yang sedang berkembang seperti Indonesia (Bilfaqih \& Qomarudin, 2015), dan sudah banyak diterapkan oleh berbagai negara termasuk Indonesia untuk menjawab tuntutan era industri 4.0. Pembelajaran online atau jarak jauh bukan hanya membutuhkan sarana prasarana yang mendukung tetapi juga sumber daya manusia yang melek teknologi, mampu menyesuaikan diri dengan perubahan, inovatif dan kreatif. Para pendidik termasuk pendidik di gereja yang dikenal dengan panggilan guru Sekolah Minggu dipacu untuk meningkatkan kompetensi diri sebagai seorang fasilitator dan motivator dalam mempersiapkan 
proses pembelajaran dan memotovasi peserta didik untuk terus belajar agar proses pembelajaran dapat tetap berjalan dengan baik walaupun sedang dilanda pandemi Covid-19.

Pada masa pandemi Covid-19 sampai pada kenormalan baru ini ada beberapa media teknologi yang digunakan dalam pembelajaran di dunia pendidikan. Antara lain e-learning, yang tidak hanya digunakan untuk menyampaikan materi pembelajaran tetapi juga meningkatkan kemampuan peserta didik. Karena melalui elearning, peserta didik selain mendengar apa yang diajarkan oleh pendidik tetapi juga aktif mengamati, mencari, menemukan dan melakukan apa yang harus dipelajarinya. Selain itu bahan ajar dapat divirtualisasikan dalam lebih menarik sehingga mampu meningkatkan motivasi belajar peserta didik. (Hartono,2016) Ada beberapa keunggulan pembelajaran berbasis elearning dengan pembelajaran yang konvensional yang dikemukakan oleh P3AI-LP3 UNEJ dan dikutip Rusman (2018:140), antara lain pertama, fleksibel dalam segi waktu dan tempat. Melalui pembelajaran elearning peserta didik dapat belajar secara fleksibel sesuai waktu yang tersedia dan di tempat yang fleksibel. Kedua, fleksibel dari segi fasilitas dan lingkungan belajar. Pembelajaran berbasis elearning memungkinkan peserta didik menggunakan fasilitas yang bervariasi dan lingkungan belajar yang nyaman. Ketiga, suasana belajar yang tidak menegangkan. Karena pembelajaran dilakukan dalam jaringan internet bukan tatap muka secara langsung maka peserta didik dapat mengekspresikan kemampuannya tanpa merasa takut dan malu jika melakukan kesalahan. Keempat, materi belajar dapat dengan mudah disesuaikan dengan tuntutan perkembangan ilmu pengetahuan dan kebutuhan peserta didik. Selain elearning, teknologi informasi lain yang digunakan adalah whatshaap, youtube, google meet dan zoom untuk tetap mempertemukan pendidik dan peserta didik dalam kegiatan pembelajaran.

Pembelajaran jarak jauh di masa kenormalan baru ini juga menuntut para guru Sekolah Minggu untuk semakin meningkatkan kualitas dirinya sebagai pendidik di era industri 4.0 bukan hanya tentang bagaimana melaksanakan proses pembelajaran, tetapi juga bagaimana membentuk karakter peserta didik dan memotivasi peserta didik untuk dapat menyesuaikan diri dalam pembelajaran jarak jauh dengan berbagai tantangan yang akan dihadapi, agar pembelajaran dapat tetap berlangsung dengan baik untuk mencapai tujuan yang diharapkan baik itu tujuan pembelajaran maupun tujuan akhir dari pendidikan di Sekolah Minggu.

\section{Sekolah Minggu sebagai Layanan Pendidikan dan Pembelajaran di Gereja}

Kehadiran gereja sebagai persekutuan orang percaya di dunia ini memiliki salah satu tanggung jawab untuk melaksanakan kegiatan pembejaran bagi umatnya agar terus bertumbuh menjadi agen-agen pembawa syalom Allah bagi dunia dan sesama. Gereja adalah tempat yang disediakan Allah untuk belajar mengenal-Nya. Menurut Nainggolan (2008:17) gereja telah ditetapkan Allah untuk melakukan tugas pembelajaran agar orang-orang percaya menjalani hidupnya dengan terus bertumbuh di dalam iman kepada Allah. Pembelajaran yang dilaksanakan oleh gereja salah satunya melalui layanan Sekolah Minggu. Harry M. Pilland ( 1984:7) mengemukakan bahwa Sekolah Minggu adalah wadah pelayanan yang penting dalam menjangkau orang-orang bagi Kristus dan dalam mengembangkan mereka menjadi seperti Dia. Sedangkan Ralph Riggs (1983: 3) menyatakan bahwa dari semua ladang injil, Sekolah Minggu adalah ladang yang paling subur untuk membawa anak-anak mengenal Allah sedini mungkin. Ladang penginjilan ini memiliki peran penting menurut Paulus Lie (2003:119). Pertama, memperkenalkan keselamatan bagi anak-anak, sehingga mereka dapat mengenal dan menerima Kristus sebagai Juruselamat secara pribadi. Kedua, menjadi sarana untuk memperkenalkan kebenaran Firman Tuhan, sehingga menolong setiap anak mengalami pertumbuhan dalam 
kehidupan kerohaniaannya. Ketiga, melatih dan mempersiapkan setiap anak untuk menjadi penerus gereja sehingga anak dapat diajar untuk bertanggung jawab terha-dap tugas-tugas gereja dalam menciptakan persekutuan, ibadah dan kesaksian gereja yang benar.

Gereja sebagai persekutuan orang percaya dalam kehadirannya di dunia ini terpanggil untuk melaksanakan tri panggilannya koinonia, diakonia dan marturia. Panggilan ini bukan hanya milik orang-orang dewasa atau jemaat dewasa tetapi juga tanggung jawab jemaat anak di setiap gereja lokal. Anak akan bertumbuh dengan baik dan mampu mengaplikasikan tri panggilan itu dalam hidup bersama dengan sesama dan alam semesta jika fungsi Sekolah Minggu berjalan dengan baik dan benar. Karena itu Mary Go ( 1998:15)menyatakan gereja harus menyediakan lingkungan yang baik bagi Sekolah Minggu, Alkitab harus menjadi bahan utama dalam mengajar anak. Gereja harus menerima kehadiran anak-anak karena mereka merupakan motor gereja yang akan datang, selain merupakan kekuatan yang tersembunyi bagi pertumbuhan gereja. Sekolah Minggu harus dapat diakses oleh semua anak dalam jemaat untuk kelak mampu menghadirkan kerajaan Allah di dunia melalui kata, pikiran dan tindakan mereka. Melalui pendidikan Kristen, orang-orang termasuk anak-anak dituntun keluar menuju kerajaan Allah (Groome: 2010,50). Untuk itu Sekolah Minggu harus berkualitas baik agar dapat menjadi lingkungan belajar yang kondusif bagi perkembangan anak. (Leheba: 2007,12).

\section{Menjadi Guru Sekolah Minggu Yang Bermakna}

Transformasi adalah sebuah kata yang berasal dari bahasa Latin transformare yang memiliki arti mengubah bentuk. Agustinus Widarnato mengutip Gouillart (2016) menyatakan transformasi adalah peralihan benatuk dari satu masa ke masa berikutnya karena adanya inovasiinovasi baik secara struktural maupun prosedural, terencana maupun tidak terencana, berlangsung terus menerus. Transformasi meliputi mengkerangka ulang, menstruktur ulang, menyusun ulang prioritas, dan pembaharuan. Ashori (2004:24-27) merumuskan bahwa dalam transformasi pembelajaran tujuan dari pembelajaran dapat dicapai jika pembelajaran tersebut bermakna, integratif, berbasis nilai, menantang dan aktif. Karena itu menurut penulis transformasi pembelajaran harus dimulai dari guru yang mau terus menerus berubah untuk menjawab kebutuhan anak didik sesuai perkembangan zaman.

Guru sekolah Minggu merupakan tokoh utama atau atau tokoh kunci suksesnya program pendidikan dan pembelajaran di Sekolah Minggu. Ilmu pengetahuan bahkan teknologi dapat berkembang dengan pesat namun jika guru Sekolah Minggu tidak mengikuti perkembangan ilmu pengetahuan dan teknolgi tersebut maka tujuan pembelajaran tidak akan tercapai oleh setiap anak didik, apalagi anak didik saat ini adalah anak-anak didik yang dikenal dengan anak didik generasi milineal. Jadi bukan hanya karena wabah pandemi covid 19 yang mengharuskan para guru Sekolah Minggu memiliki kemampuan menggunakan teknologi dalam proses pembelajaran tetapi juga karena diperhadapkan dengan karakteristik anak didik generasi milenial. Ferdinand Lafendry (2019:10-11) mengemukakan karakteristik generasi milenial, pertama, pengguna teknologi yang cerdas. Generasi ini mengenal dunia melalui media sosial, pahami seluk beluk teknologi, bahkan hidup mereka tak terpisahkan dari teknologi. Kedua, independen. Generasi ini tidak menunggu orang tua untuk mengajar mereka tetapi mereka dapat belajar sendiri langsung dari media sosial. Ketiga, beragam. Ini generasi yang paling beragam dalam membentuk kelompok pertemanan melalui media sosial. Keempat, memerlukan konektivitas. Penelitian yang dilakukan oleh Goldman Sachs mengetengahkan hampir setengah generasi $Z$ atau milenial ini terhubung secara online selama sepuluh jam sehari bahkan lebih. 
Pembelajaran di Sekolah Minggu dilakukan bukan sekedar sebagai kewajiban semata dari gereja sebagai persekutuan yang mengajar, tetapi setiap pembelajaran yang dilakukan harus dapat mencapai baik tujuan dqari pembelajaran tersebut tetapi juga tujuan dari Sekolah Minggu di tiap gereja lokal. Karena itu kemampuan terhadap tugas perkembangan dan karakteristik anak-anak didik di Sekolah Minggu juga seharusnya dipahami oleh guru Sekolah Minggu. Guru sekolah Minggu bagi generasi milenial harus memiliki beberapa kriteria (Lafendry :2019:17) yaitu, pertama, kekinian. Guru mampu beradaptasi dengan kehidupan generasi milenial. Kedua, Menguasai pembelajaran kontekstual. Guru mampu memadukan teori atau materi ajar dengan contoh nyata kehidupan anak didik. Ketiga, Mengikuti perkembangan teknologi. Tiap guru dituntut mampu mengikuti perkembangan teknologi umtuk dapat membimbing dan mengajar anak didik yang dikenal dengan istilah kids zaman now ini.

Penulis menyadari bahwa guru Sekolah Minggu berbeda dengan guru Pendidikan Agama Kristen di lembaga pendidikan formal yang ada pada jenjang pendidikan anak usia dini hingga jenjang pendidikan menengah yang telah terdidik dan terlatih dengan berbagai kompetensi selama ada pada masa pendidikan di perguruan tinggi. Tetapi guru sekolah Minggu telah memiliki modal utama adalah rasa keterpanggilan untuk melayani anak-anak yang ada pada masing-masing gereja lokal. Rasa keterpanggilan ini seharusnya mendorong guru sekolah mengikuti untuk tetap berusaha mengikuti perkembangan ilmu pengetahuan dan teknologi juga perkembangan generasi ke generasi yang dilayaninya. Panggilan itu harus dirasakan sebagai panggilan secara pribadi yang datang dari dalam diri guru sekolah Minggu secara pribadi, karena pada waktunya panggilan itu harus dapat dipertanggungjawabkan (Homrighaussen dan Enklaar: 2004:13-14). Palmer bahkan menekankan panggilan itu akan memampukan para guru untuk menghargai karakter jati diri sebagai seorang pelayan dan pengajar sesuangguhnya. (2009:44). Kesadaran akan panggilan suci itu merupakan kesadaran moral yang melahirkan kehendak baik untuk melaksanakan panggilan tersebut sebagai suatu kewajiban mutlak yang tidak dapat ditawar, dan itulah budi paling luhur. (Jansen Sinamo dan Eben Ezer: 2011, 166).

Kenneth O. Gangel mengutip pandangan Gaebelein (2001:44) yang mengemukakan beberapa persyaratan bagi guru Kristen termasuk guru Sekolah Minggu di antaranya adalah pertama, guru harus mencari mutu terbaik di bidang intelektual untuk kemuliaan Allah, karena itu harus terus berjuang untuk memnuhi berbagai persyaratan dari dunia untuk seorang guru. Kedua, harus benar-benar mengasihi anak didiknya dan mengusahakan yang terbaik bagi mereka sekalipun terkadang hal itu sulit untuk dilakukan. Ketiga, guru harus patuh sepenuhnya kepada Sang guru Agung yang telah memilih dan mengutusnya. Gangel dan Hendrick yang dikutip Sidjabat (2009:52) beberapa hal yang dapat diteladani oleh guru dari Yesus Sang Guru Agung yakni, pertama, kepribadian Yesus di mana Yesus melakukan apa yang diajari-Nya. Kedua, Yesus melakukan apa yang diajarkan-Nya, bersikap realistis dan relasional atau bersahabat dengan mereka yang diajar. Ketiga, Pengajaran-Nya relevan, otoritatif, efektif dan metode yang digunakan Yesus sangat kreatif. Soal keteladanan Yesus dalam hal melakukan pembelajaran juga ditekankan oleh J.M Price (2011:52) yakni Yesus berhasrat untuk menolong. Salah satu syarat yang penting bagi setiap pendidik Kristen adalah sifat memerhatikan keperluan orang lain dan hasrat untuk menolong orang lain. Walaupun seorang pendidik mempunyai pengetahuan Alkitab yang mendalam, mengenal peserta didiknya dengan baik, dan menguasai metode-metode mengajar, namun jika tidak memiliki sifat memerhatikan keperluan peserta didik dan hasrat untuk menolong, maka pendidik seperti gong yang berbunyi, atau genta yang gemerincing. Yesus mengasihi orang dan memerhatikan persoalan- 
persoalan yang dihadapi, la tidak hanya menaruh perhatian kepada masalah-masalah orang lain, tetapi la berbuat sesuatu untuk meolong mereka (Mrk. 10:12).

\section{Pembelajaran Sekolah Minggu yang Memerdekakan}

Pembelajaran pada hakikatnya merupakan proses membelajarkan peserta didik bagaimana mereka belajar, mencari, menemukan dan melakukan apa yang telah mereka ketahui melalui proses belajar. Dengan kata lain pembelajaran memberikan ruang yang cukup, kebebasan serta menantang untuk anak didik belajar secara aktif, mandiri, kreatif dan bertanggung jawab sehingga pembelajaran yang dilakukan lebih bermakna bagi anak didik. Hal ini juga harus berlangsung bagi pembelajaran yang dilakukan di Sekolah Minggu. Mulyasa (2021: 168173) menggunakan Istilah pembelajaran "MERDEKA" yang merupakan singkatan dari pembelajaran Menyenangkan, Efektif, Rekreatif, Demokratis, Empatik, Kreatif, dan Aktif, dengan penjelasan sebagai berikut:

Pertama, Menyenangkan. Guru harus menempatkan anak didik sebagai mitra belajar dengan menjalin pola hubungan yang baik bahkan dapat belajar dari anak didik. Guru harus menciptakan suasana belajar yang menyenangkan dan tidak membebani anak didik, mengembangkan program dengan baik, memilih materi yang tepat serta mengembangkan strategi yang dapat melibatkan anak didik dengan optimal. Kedua. Efektif. Pembelajaran yang dilakukan dapat memberikan pengalaman baru bagi anak didik serta membentuk kompetensi mereka untuk mencapai tujuan yang telah ditetapkan. Ketiga, Rekreatif. Dalam melakukan pembelajaran diharapkan guru menciptakan lingkungan belajar dengan suasana yang gembira sehingga peserta didik merasa asyik tetapi sekaligus mencerdaskan. Keempat, Demokratis. Pembelajaran dilakukan dengan berpusat pada pertumbuhan dan perkembangan anak didik sesuai kodratnya. Kelima, Empatik. Proses pembelajaran harus dapat memotivasi anak didik untuk merasakan apa yang dirasakan oleh orang lain. Keenam, Kretif. Pembelajaran yang dilakukan harus mampu memunculkan kreativitas peserta didik dalam hal berpikir maupun berperilaku. Ketujuh, Aktif. Pembelajaran yang dilakukan lebih didominasi oleh aktivitas anak didik dalam mencari dan menemukan pengetahuan serta keterampilan yang harus dimilikinya. J.B. Mangunwijaya (2020:170) menyatakan pada pendidikan dan pembelajaran zaman ini unsur bertanya, menyelidiki, meneliti dan eksplorasi adalah penting dan menjadi kunci kemajuan anak didik.

Lafendry (2019:13) dalam melaksanakan pembelajaran bagi generasi milenial, teknologi informasi dan komunikasi menjadi alat bantu dalam upaya mencapai tujuan pembelajaran yang mengutamakan kemampuan keterampilan dan kecakapan anak didik. Untuk itu guru dituntut untuk melakukan pembelajaran secara kreatif dan menarik dalam mengkombinasikan penyampaian materi yang menarik dengan teknologi sehingga pembelajaran menjadi menarik dan menantang bagi anak didik. Teknologi dalam pembelajaran sudah banyak digunakan yang dimulai dari pemanfaatan komputer, e-book, elearning, poyektor, dan lain-lain dengan ada yang sifatnya audio, visual maupun audio visial. (Ditta W. Utama dan Richardus E. Indrajit: 2020, 4)

Bagi pendidikan Kristen sendiri menurut Wolterstorff yang dikutip Khoe Yao Tung (2016:229) memiliki tujuan untuk memperlengkapi para guru menjadi agen, model dan saksi bagi syalom untuk mewujudkan perdamain, keadilan dan kesejahteraan manusia. Wolterstorff (2010:348) mengemukakan dalam hubungan dengan syalom, pendidik Kristen harus menjadikan kerja untuk syalom yang berarti bekerja untuk megembangkan potensi ciptaan, bekerja untuk menyembuhkan penyakit atau atau kerusakan dalam hubungan-hubungan antar sesama. 
Gangel (2001:53) menyatakan tujuan pendidikan Kristen di gereja lokal umumnya adalah untuk menghasilkan kedewasaan iman yang sempurna dalam kehidupan anggota gerejanya.

\section{Penutup}

Untuk melaksanakan pembelajaran yang memerdekaan di sekolah Minggu, beberapa motede pembelajaran dapat dilakukan oelh guru sekolah Minggu, yaitu. pertama, demonstrasi. Metode di mana guru menunjukkan suatu proses, peristiwa atau cara kerja suatu alat kepada anak didik bukan sekedar untuk diketahui tetapi juga dapat dilakukan oleh anak didik untuk memecahkan sebuah masalah. Kedua, penemuan. Yang lebih mengutamakan pengalaman langsung anak didik dan mengutamakan proses belajar dari pada hasil belajar. Ketiga, Eksperimen. Pembelajaran yang melibatkan anak didik bekerja secara langsung dengan bendabenda atau bahan-bahan di sekitar mereka. Keempat, Pemecahan Masalah. Pembembelajaran dilakukan dengan memberikan kepada peserta didik suatu masalah yang harus diselesaikan oleh mereka. Kelima, Karyawisata. Suatu aktivitas pembelajaran dengan membawa anak didik ke sumber belajar tertentu untuk memperoleh pengalaman belajar secara langsung yang terintegrasi dengan kurikulum sekolah Minggu.

\section{REFERENSI}

Gangel Kenneth O., 2001, Membina Pemimpin Pendidikan Kristen, Malang, Gandum Mas

Groome, Thomas H., Christian Religious Education; Berbagi Cerita \& Visi Kita, terj. Daniel Stefanus, Jakarta: BPK Gunung Mulia, 2010

Homrighausen, E.G. dan Enklaar I.H, Pendidikan Agama Kristen, Jakarta: BPK Gunung Mulia, 2004.

Lafendry Ferdinand, 2019, Guru Kreatif yang menyenangkan Pada Era Milenial, Jakarta, Jakarta, Salemba Humanika

Laheba, Novelina, Guruku Sahabatku, Panduan Mengajar Kreatif untuk Guru Sekolah Minggu, Jogjakarta: ANDI, 2007

Lie, Paulus, Mereformasi Sekolah Minggu, 8 Kiat untuk Menjadikan Sekolah Minggu Berpusat Pada Anak, Yogjakarta: ANDI, 2003).

Mangunwijaya, Y.B., 2020, Sekolah Merdeka, Jakarta, Buku Kompas

Mulyasa H.E., 2020, Menjadi Guru Penggerak Merdeka Belajar, Jakarta, Bumi Aksara

Nainggolan, J.M., Strategi Pembinaan Warga Gereja, Bandung: Generasi Info Media, 2008.

Palmer, Parker J., Keberanian Mengajar, Menjelajah Ruang Nurani Kehidupan Guru, Jakarta: Indeks, 2009.

Pilland, Harry M., Basic Sunday School Work, Nashville Tennesse: Baptis Book Store, 1987.

Price J.M., 2011, Yesus Guru Agung, Terj. Jachin Karuniadi, Bandung, Yayasan Literatur Baptis.

Sidjabat B.S., 2009, Mengajar Secara Prpfesional; Mewujudkan Visi Guru Profesional, Bandung, Yayasan Kalam Hidup.

Utami Ditta Widya dan Indrajit R.E., 2020, Menyongsong Era Baru Pendidikan, Yogyakarta, ANDI

Woltersstorff N.P., 2010, Mendidik Untuk Kehidupan, Surabaya, Momentum 